Egyptian Journal of Rabbit Science, 30(2): 93- 109 (2020)

\title{
EFFECT OF DIETARY LEMONGRASS OIL OR VITAMIN E ON PERFORMANCE, DIGESTIBILITY COEFFICIENTS, CARCASS TRAITS AND MEAT QUALITY OF RABBITS
}

\author{
H. M. A. EL-Komy; Enayat H. AboEl-Azayem and G.E. Younan \\ Animal Production Research Institute, Agriculture Research Center, Dokki, Giza, \\ Egypt.e.mail:drhamdyelkomy2008@yahoo.comm
}

ABSTRACT: This study was conducted to determine the effect of supplemented rabbit diets with lemongrass (Cymbopogoncitratus) oil

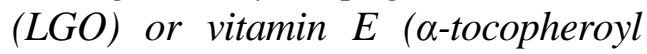
acetate, Vit E) on performance, digestibility coefficients, carcass traits and meat quality of rabbits. Sixty growing New Zealand White (NZW) rabbits aged 8 weeks were divided randomly into four equal groups with three replicate (5 rabbit in each). Rabbits were distributed into four dietary treatments included a control diet without any feed additive, a diet containing 150mg Vit E $/ \mathrm{kg}$ diet, Vit E,

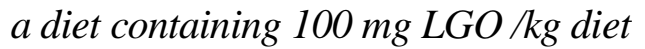
and a diet containing $150 \mathrm{mg} \mathrm{LGO} / \mathrm{kg}$ diet during the growth period. Rabbits were fed to allow ad-libitum in feeding trial lasted 56 days.

The results showed that rabbits fed diet contain $150 \mathrm{mg}$ Vit $\mathrm{E} / \mathrm{kg}$ diet and $150 \mathrm{mg} \quad \mathrm{LGO} \quad \mathrm{kg}$ diet recorded significantly higher final live weight and total weight gain as compared to the control and group fed diet contained $100 \mathrm{mg} \mathrm{LGO} \mathrm{kg}$ diet.
Rabbits fed dietary $150 \mathrm{mg}$ LGO recorded the best feed conversion ratio. The digestibility coefficients for $C P$ and nutritive values in terms DCP and TDN of were significantly higher with Vit E and LGO supplementation. Supplementing $150 \mathrm{mg} / \mathrm{kg}$ diet Vit E increased significantly $(P<0.05) O M$ digestibility coefficient. Adding LGO supplementation to rabbit diets significantly $\quad(P<0.01) \quad$ increased carcass, dressing and total edible parts percentages. However, there were no significant differences between groups for heart, kidney, liver and giblets percentages. Total cholesterol content in meat decreased significantly $(P<0.05)$ decreased in group fed 150 mg LGO as compared to the control group. Triglycerides and MDA concentrations were significantly lower in treatments group when compared with the control. There were no significant between experimental diets in pHu of meat, while drip loss \% were significantly $(P<0.05)$ decreased compared to those of the control. 
Conclusively, it could be concluded that adding lemongrass oil or vitamin $E$ as feed supplementation in growing rabbit's diet improved growth performance, digestion coefficients dressing percentages and meat quality. Also, supplemented rabbits diet 150 mg LGO/kg diet led to improvement economic efficiency than that of 150 $m g$ Vit $\mathrm{E} / \mathrm{kg}$ diet and free from additives.

Keywords: Lemongrass oil, Vitamin E, Growth performance, Nutrients digestibility, Carcass characteristics, Meat quality.

\section{INTRODUCTION}

Rabbit meat represents excellent nutritive prosperities as it is highly digestible and tasty (Combes, 2004; Hern 'andez and Gondret, 2006). This meat is lean, rich in proteins, low in cholesterol and high in polyunsaturated fatty acids, which enhance human health (Bazan, et al., 2011; Wall et al., 2010). During metabolism, the body produces antioxidant gets rid of free radicals produced (oxidants), but oxidative stress develops when oxidants generation exceeds the body's antioxidant production (Roth, 2000). Lipid oxidation changes the meat flavor, texture and nutritional (Gil et al., 2001).

In the last decade, food industry has used synthetic antioxidants (BrandWilliams et al., 1995), which is considered a health risk (Hettiarachchy et al., 1996), besides consumers prefer natural antioxidants than synthetic (Barlow, 1990). Animal feed influence the meat composition of mono gastric livestock. Supplementing rabbit diets with plant extract and vitamin E improve meat quality (Botsoglou et al., 2004; Cardinali et al., 2015). The natural antioxidant may effectively inhibit the oxidation of muscle tissue (Botsoglou et al., 2004) and protects cellular membranes against oxidative damage (Morissey et al., 1994). Besides, these natural additives enhance the taste and improving the flavor of the feed and have positive effects on digestion and intestinal health and enhanced animal performance (Krieg et al., 2009).

Lemon grass (Cymbopogon citrates) is an aromatic perennial plant of the family Poaceae that has been used to extract essential oils. It is grown around the world and has used in traditional therapeutic in many countries (Aftab et al., 2011; Tarkang et al., 2012). Cymbopogon citrates essential oil has many pharmaceutical activities as antibacterial (Wannissorn, et al., 2005), antifungal (Nakagawa et al., 2003), antiprotozoal (Holetz et al., 2003), antioxidant (Masuda et al., 2008), anti-inflammatory (Abe et al., 2004), anti-carcinogenic 
(Puatonachokchai et al., 2002) and cardio protective (Gazola et al., 2004). It has also been used to treat diabetes (Mansour et al., 2002), gastrointestinal disturbances (Carlini et al., 1986) and flu, fever, and pneumonia (Negrelle and Gomes, 2007), as well as inhibit platelet aggregation (Tognolini et al., 2006).

The essential oil of Cymbopogon citrates contains Citral, myrcene, geranial, geraniol, limonene, burneol, citronellol, nerol, neral, $\alpha$-terpineol, elemicin, caffeic acid, apigenin, luteolin, kaempferol, quercetin, chlorogenic acid, and geranyl acetate (Bharti et al., 2013). It also contains fumesol, furfurol, isopulegol, isovaleranic aldehyde, L-linanool, methylheptenone, n-decyclic aldehyde, terpineone, p-coumaric acid, valeric and esters (Negrelle and Gomes, 2007; Akhila, 2010; Faruq, 1994). Kassahun and Gezu (2019) reported that the essential oil of lemon grass contains twenty volatile components, and the main components are alpha-pinene (25.55\%), D-limonene (5.69\%) and eucalyptol (55.43\%), also eucalyptol is major constituent which is aromatic in nature. On the other hand, Negrelle and Gomes (2007) showed that citral is the high content of essential oil (about 80\%) which is responsible for the lemony smell.

Vitamin E which is considered as nature antioxidant (Brigelius-Flohe and Bold, 1999), has several other biological activities such as regulation of cellular signaling and gene activity and modulation of immune function (Azzi et al., 2002; Brigelius-Flohe et al., 2002).

Therefore, the aim of the present study was to investigate the effect of lemon grass oil and vitamin E supplementation on performance, digestibility, carcass characteristics and meat quality of growing rabbits.

\section{MATERIALS AND METHODS}

\section{Animal, management and dietary treatments}

A total number of sixty New Zealand White (NZW) weaned rabbits at 6 weeks were allocated to four dietary groups. Rabbits were individually housed in wire cage and drinking water and diets were supplied ad-libitum. The experimental period lasted for 56 days and first group was the control group with no additive. The second group supplemented with vitamin E $(150 \mathrm{mg} / \mathrm{kg}$ diet $)$. The third and fourth groups were supplemented with lemon grass oil (LGO) at 100 and $150 \mathrm{mg} / \mathrm{kg}$ diet, respectively. All diets were iso-nitrogenous and isoenergetic. The chemical composition of the experimental diets was reported in Table 1. Basal diet was formulated according to NRC (1977). 
Table1:Ingredients and chemical composition of the basal experimental diet of growing rabbits.

\begin{tabular}{|l|c|}
\hline Items & \%as feed \\
\hline Ingredients: & 28.00 \\
\hline Alfaalfa hay 15\% & 21.35 \\
\hline wheat bran & 18.40 \\
\hline Barley & 11.20 \\
\hline Yellow corn & 14.75 \\
\hline Soybean meal 44\% & 2.50 \\
\hline Molasses & 2.20 \\
\hline Di calcium phosphate & 0.70 \\
\hline Calcium carbonate & 0.30 \\
\hline Sodium chloride & 0.30 \\
\hline Vitamins and minerals premix & 0.30 \\
\hline DL-Methionine & $\mathbf{1 0 0}$ \\
\hline Total & \\
\hline Calculated chemical composition & 17.44 \\
\hline Crude protein (\%) & 24959 \\
\hline Digestible energy, kcal/kg & 2.45 \\
\hline Ether extract (\%) & 12.25 \\
\hline Crude fiber (\%) & 1.17 \\
\hline Calcium (\%) & 0.92 \\
\hline Total p (\%) & 0.18 \\
\hline Na (\%) & 0.82 \\
\hline Lysine (\%) & 0.54 \\
\hline Methionine (\%) & 0.82 \\
\hline Methionine+ Cyctine (\%) & \\
\hline IMner| & \\
\hline
\end{tabular}

${ }^{\mathrm{I}}$ Mineral and vitamin mixture supplied per kg of diet: Vitamin A 60000 IU, Vitamin D3; 900 UI, Vitamin E; 40 mg, vitamin K3; 2 mg, Vitamin B1; 2mg, Vitamin B2; 4 mg, Vitamin B6;

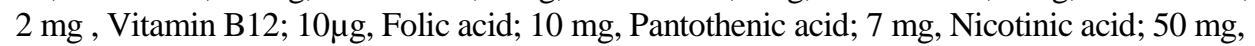
Biotin; $50 \mu \mathrm{g}$, Choline chloride; $250 \mathrm{mg}$, I; $0.2 \mathrm{mg}, \mathrm{Mn} ; 85 \mathrm{mg}, \mathrm{Cu} ; 5 \mathrm{mg}, \mathrm{Zn} ; 50 \mathrm{mg}$, Fe; 50 $\mathrm{mg}, \mathrm{Co}$; $0.1 \mathrm{mg}$, Selenium; $0.1 \mathrm{mg}$.

\section{Growth performance}

Live body weight and feed intake were recording weekly from weaning to the end of experimental period. The change in live body weight during 
experimental period was calculated as the weight gain, also the feed conversion ratio was calculated.

\section{Nutrient digestibility coefficients}

At the last week of the experimental period (14 weeks of age) a digestion trail was run to demine digestibility of nutrients. Samples of feed and feces were daily collected form rabbit (4 per each treatment). Rabbits were individually housed in metabolic cages which fresh water and diets were daily provided. The feces samples were oven- dried at $60^{\circ} \mathrm{C}$ for $24 \mathrm{~h}$ and then were ground for chemical analyses. Digestibility of nutrients was measured as described by Cheeke (1987). Chemical analyses of diets and feces were done according to the classical (AOAC, 1996).

\section{Carcass characteristics}

At the end of the growth experiment, three rabbits of each treatment were fasted for 12 hours, and then slaughtered. The hot carcass, liver, kidneys and heart were weighted calculated as percentage from live body weight; also the dressing, giblets and total edible parts were calculated as percentage from live body weight.

\section{Meat quality}

Three carcasses from each group were randomly collected and used for meat quality analyses at $24 \mathrm{~h}$ post mortem $\left(2-4^{\circ} \mathrm{C}\right)$. The L. lumborum muscles (between the 1 st and 7 th lumbar vertebra) were used to determine ultimate $\mathrm{pH}$ $(\mathrm{pHu})$ and drip loss. The ultimate $\mathrm{pH}(\mathrm{pHu})$ was measured on the same muscles and then each carcass was dissected as recommended by Blasco, et al., (1993). Drip loss (DL) was determined as the percentage of the difference between weights before and after chilling for $24 \mathrm{~h}$. and divided by the first weight according to Lundström and Malmfors, (1985).The cooking loss was determined according to Omojola and Adesehinwa, (2006).

Furthermore, Mixture of meat were stored on $-20^{\circ} \mathrm{C}$ for 4 days before chemical measurements, total protein, total cholesterol, triglycerides and malondialdehyde (MDA) contents were determined by colorimetric methods using analytical kits produced by Biodiagnostic Company, Egypt.

\section{Statistical analysis:}

Data were statistically analyzed using Least Squares Analysis of Variance according to Snedecor and Cochran (1982) using the general linear model (GLM) procedure of SAS User's guide (SAS, 2001) using the following fixed model: 


$$
\mathrm{Y}_{\mathrm{ij}}=\mu+\mathrm{Ti}+\mathrm{e}_{\mathrm{ij}}
$$

Where, $Y_{\mathrm{ij}}=$ The observed value of a given dependent variable, $\mu=$ Overall adjusted mean, $\mathrm{Ti}=$ Fixed effect of the treatments, $\mathrm{i}=1,2 \ldots \ldots \ldots \ldots, \mathrm{e}_{\mathrm{ij}}=$ Random error of the model.

The differences between LSM (least square means) were analyzed by Duncan's New Multiple Range test (Duncan, 1955). Data in percentage values were transformed with the arcsine square root procedure to normalize variance before analysis.

\section{RESULTS AND DISCUSSIONS}

\section{Growth performance}

The effects of dietary LGO and VitE on the performance of growing rabbits are shown in Table 2. There were no difference in final live weight and total weight gain between rabbits fed diet contained $100 \mathrm{mg} \mathrm{LGO} / \mathrm{kg}$ diet and the control group. On the other hand, rabbits fed basal diet supplemented with $150 \mathrm{mg}$ $\mathrm{VitE} / \mathrm{kg}$ diet and

Table 2: Effect of supplementing diet with lemongrass (LGO) and VitE on rabbit performance.

\begin{tabular}{|c|c|c|c|c|c|c|}
\hline \multirow{2}{*}{ Items } & \multicolumn{4}{|c|}{ Experimental groups } & \multirow{2}{*}{$\begin{array}{c}\text { Pooled } \\
\text { SE }\end{array}$} & \multirow{2}{*}{ Sig } \\
\hline & Control & $\begin{array}{c}\text { VitE150 } \\
\mathrm{mg} / \mathrm{kg}\end{array}$ & $\begin{array}{c}\text { LGO100 } \\
\mathrm{mg} / \mathrm{kg}\end{array}$ & $\begin{array}{c}\text { LGO150 } \\
\mathrm{mg} / \mathrm{kg}\end{array}$ & & \\
\hline Initial live weight (g) & 735 & 733.75 & 745.63 & 700.63 & 43.94 & NS \\
\hline Final live weight (g) & $2278.75^{\mathrm{b}}$ & $2446.25^{\mathrm{a}}$ & $2303.13^{b}$ & $2448.75^{\mathrm{a}}$ & 40.18 & ** \\
\hline Total weight gain $(\mathrm{g})$ & $1543.75^{\mathrm{b}}$ & $1712.5^{\mathrm{a}}$ & $1557.5^{\mathrm{b}}$ & $1748.13^{\mathrm{a}}$ & 16.68 & ** \\
\hline Total feed intake (g) & $5456.63^{\mathrm{ab}}$ & $5544.63^{\mathrm{a}}$ & $5290^{c}$ & $5324^{\text {bc }}$ & 54.6 & ** \\
\hline FCR & $3.53^{\mathrm{a}}$ & $3.24^{\mathrm{c}}$ & $3.4^{\mathrm{b}}$ & $3.05^{\mathrm{d}}$ & 0.01 & ** \\
\hline
\end{tabular}

a, b.... Means within each row have no similar letters are significantly different $(\mathrm{P} \leq 0.01)$

$150 \mathrm{mg}$ LGO $/ \mathrm{kg}$ diet significantly $(\mathrm{P}<0.01)$ recorded higher final live weight by $7.35 \%$ and $7.46 \%$, respectively and higher total weight gain by 10.93 and $13.24 \%$, respectively compared to the control group. There were no significant differences in final live weight and total weight gain between rabbits fed basal diet supplemented with $150 \mathrm{mg} \mathrm{VitE} / \mathrm{kg}$ diet and $150 \mathrm{mg} \mathrm{LGO} / \mathrm{kg}$ diet. Total feed intake was significantly decreased with supplementing diets with $100 \mathrm{mg}$ LGO $/ \mathrm{kg}$. Feed 
conversion ratios were significantly improved with supplemented diets with 150 $\mathrm{mg} / \mathrm{kg}$ diet VitE and 100 and $150 \mathrm{mg} \mathrm{LGO} / \mathrm{kg}$ by $8.21,3.68$ and $13.6 \%$ compared with the control group, and the best group was contained $150 \mathrm{mg} \mathrm{LGO} / \mathrm{kg}$.

These results are in agreement with Selim, et al., (2008) who found that supplementing diets with vitamin E improved growth performance of growing rabbits. On the other hand, Al-Sagheer, et al. (2017a) reported that supplemented growing New Zealand rabbit diets with lemon grass oil increased live body weight and daily body weight gain and improved feed conversion ratio. Also, Malee, et al., (2000) concluded that addition of lemon grass oil to weanling pig diets were significantly increased the productive performance. While, Al-Sagheer, et al., (2017b) observed an improvement in growth performance of fish fed diets supplemented with 200 and $400 \mathrm{mg}$ LGO $/ \mathrm{kg}$ as compared with control group. The same trend observed in broiler chickens, Tiwari et al., (2019) found that supplemented diet with $400 \mathrm{ml} / 100 \mathrm{LGO} / \mathrm{kg}$ diet improved growth performance. The improvement in growth performance could be due to the antioxidant activity of Vit E (Brigelius-Flohe and Traber, 1999) and LGO (Masuda, et al., 2008), which improved the antioxidant status of rabbits. The growth enhancing effect of LGO could be strongly correlated with their strong antibacterial (Wannissorn et al., 2005) and antimicrobial activity (Oussalah et al., 2007). Also, citral has an immunomodulatory activity (Bachiegaand Sforcin, 2011), and Vit E modulate the immune function (Azzi et al., 2002).

\section{Nutrient digestibility coefficients}

The effects of dietary supplementation with VitE and LGO on nutrient digestibility coefficients and nutritive values of growing rabbits are graphically presented in Table 3.

There were no difference between treatments in DM, CF, EE and NFE digestibility coefficients among treatments. The digestibility coefficients of OM and $\mathrm{CP}$ increased significantly increased in the experimental diets contained $150 \mathrm{mg}$ Vit $\mathrm{E} / \mathrm{kg}$ diet as compared with the control and the group contained 100mg LGO / kg diet. Nutritive values (TDN and DCP) significantly increased in experimental diets compared to control diet. In this respect, Al-Sagheer et al., (2017a) showed that digestibility of $\mathrm{CP}$ and the nutritive values of DCP significantly $(\mathrm{P}<0.05)$ increase with LGO supplementation to the heat-stressed growing rabbits as compared to control group. The positive effect of Vit E and LGO on the digestibility traits may be due to that both of them have antioxidant activity ((Brigelius-Flohe and bold, 1999 and Masuda et al., 2008). 
Table 3: Effect of supplementing diet with lemongrass (LGO) and Vit E on Nutrient digestibility coefficients and nutritive values of growing rabbits:

\begin{tabular}{|c|c|c|c|c|c|c|}
\hline \multirow[b]{2}{*}{ Items } & \multicolumn{4}{|c|}{ Experimental groups } & \multirow[b]{2}{*}{ Pooled SE } & \multirow[b]{2}{*}{ Sig } \\
\hline & Control & $\begin{array}{c}\text { Vit E } \\
150 \mathrm{mg} / \mathrm{kg}\end{array}$ & $\begin{array}{c}\text { LGO } \\
100 \mathrm{mg} / \mathrm{kg}\end{array}$ & $\begin{array}{c}\text { LGO } \\
150 \mathrm{mg} / \mathrm{kg}\end{array}$ & & \\
\hline$\overline{D M}$ & 64.12 & 67.7 & 65.1 & 65.66 & 0.56 & NS \\
\hline $\mathbf{O M}$ & $65^{\mathrm{b}}$ & $68.5^{\mathrm{a}}$ & $65.78^{b}$ & $66.2^{\mathrm{ab}}$ & 0.7 & $*$ \\
\hline $\mathbf{C P}$ & $73.81^{b}$ & $78.76^{\mathrm{a}}$ & $75.67^{\mathrm{bc}}$ & $76.53^{\mathrm{ab}}$ & 0.63 & $* *$ \\
\hline $\mathbf{C F}$ & 34.32 & 39.94 & 35.71 & 35.9 & 1.13 & NS \\
\hline $\mathbf{E E}$ & 66.92 & 71.1 & 70.17 & 69.37 & 1.15 & NS \\
\hline NFE & 68.6 & 71.17 & 68.77 & 69.2 & 0.61 & NS \\
\hline \multicolumn{7}{|c|}{ Nutritive value (\% DM) } \\
\hline DCP & $13.44^{\mathrm{c}}$ & $14.34^{\mathrm{a}}$ & $13.78^{\mathrm{bc}}$ & $13.95^{\mathrm{ab}}$ & 0.17 & $* *$ \\
\hline TDN & $61.76^{b}$ & $65.1^{\mathrm{a}}$ & $62.6^{\mathrm{b}}$ & $62.96^{\mathrm{ab}}$ & 0.5 & $*$ \\
\hline
\end{tabular}

$a, \mathrm{~b}$ and c: Means in the same row having different superscripts differ significantly.

\section{Carcass characteristics}

The effects of supplementing diet with LGO and VitE on dressing, carcass, heart, kidney, liver, giblets and total edible parte percentages are shown in Table 4. There were no significant effects due to supplementing diet with LGO and Vit E on heart, kidney, liver and giblets percentages. Supplementing growing rabbit diets with LGO significantly increased dressing, carcass and total edible parte, whereas there was no effect due to Vit E supplementing.

Omer et al., (2010) found that adding 0.5\% lemon grass to New Zealand White male rabbits aged 8 weeks significantly $(\mathrm{P}<0.05)$ increased dressing percentages (DP) calculated as carcass weight/empty body weight compared to the control diet. Al-Sagheer et al., (2017a) mentioned that there was no significant effect in dressing percentage in growing rabbits fed diet supplemented with LGO under heat-stress condition compared to the control group.

\section{Meat quality}

The effect of using LGO and Vit $\mathrm{E}$ as feed additives on growing rabbit diets on the meat traits are presented in Table 5. These results indicate that the percentages of total protein in meat were not significantly changed in the experimental groups compared with the control group. These results are in agreement with Mukhtar et al., (2012) who reported that there were no significant 
EFFECT OF DIETARY LEMONGRASS OIL OR VITAMIN E RABBITS

101

Table 4: Effect of supplementing diet with lemongrass (LGO) and VitE on carcass characteristics of rabbit of growing rabbits.

\begin{tabular}{|l|c|c|c|c|c|c|}
\hline \multirow{2}{*}{ Items } & \multicolumn{3}{|c|}{ Experimental groups } & \multirow{2}{*}{$\begin{array}{c}\text { Pooled } \\
\text { SE }\end{array}$} & \multirow{2}{*}{ Sig } \\
\cline { 2 - 6 } & Control & $\begin{array}{c}\text { VitE } \\
\mathbf{1 5 0} \mathbf{m g} / \mathbf{k g}\end{array}$ & $\begin{array}{c}\text { LGO } \\
\mathbf{1 0 0} \mathbf{m g} / \mathbf{k g}\end{array}$ & $\begin{array}{c}\text { LGO } \\
\mathbf{1 5 0 m g / k g}\end{array}$ & & \\
\hline Dressing (\%) & $54.33^{\mathrm{b}}$ & $56.08^{\mathrm{b}}$ & $72.42^{\mathrm{a}}$ & $74.62^{\mathrm{a}}$ & 5.26 & $* *$ \\
\hline Carcass (\%) & $44.73^{\mathrm{b}}$ & $45.67^{\mathrm{b}}$ & $62.9^{\mathrm{a}}$ & $65.80^{\mathrm{a}}$ & 0.4 & $* *$ \\
\hline Heart (\%) & 0.33 & 0.33 & 0.33 & 0.37 & 3.33 & NS \\
\hline Kidney (\%) & 0.7 & 0.63 & 0.63 & 0.57 & 0.07 & NS \\
\hline Liver (\%) & 0.31 & 0.38 & 0.33 & 0.27 & 0.003 & NS \\
\hline Giblets (\%) & 4.17 & 4.73 & 4.37 & 3.67 & 0.004 & NS \\
\hline Total edible parts (\%) & $48.9^{\mathrm{b}}$ & $50.4^{\mathrm{b}}$ & $67.3^{\mathrm{a}}$ & $79.5^{\mathrm{a}}$ & 0.05 & $* *$ \\
\hline
\end{tabular}

a, b.... Means within each row have no similar letters are significantly different $(\mathrm{P} \leq 0.01)$

Table 5: Effect of supplementing diet with LGO and VitE on chemical measurements of meat quality of growing.

\begin{tabular}{|c|c|c|c|c|c|c|}
\hline \multirow{2}{*}{ Items } & \multicolumn{4}{|c|}{ Experimental groups } & \multirow{2}{*}{$\begin{array}{c}\text { Pooled } \\
\text { SE }\end{array}$} & \multirow{2}{*}{ Sig } \\
\hline & Control & $\begin{array}{c}\text { VitE } \\
150 \mathrm{mg} / \mathrm{kg}\end{array}$ & $\begin{array}{c}\text { LGO } \\
100 \mathrm{mg} / \mathrm{kg}\end{array}$ & $\begin{array}{c}\text { LGO } \\
150 \mathrm{mg} / \mathrm{kg}\end{array}$ & & \\
\hline Total protein (mg/100g) & 735 & 733.75 & 745.63 & 700.63 & 43.94 & NS \\
\hline Total cholesterol (mg/100g) & $180^{\mathrm{ab}}$ & $168.33^{\mathrm{bc}}$ & $186.67^{\mathrm{a}}$ & $167.5^{\mathrm{c}}$ & 0.01 & $*$ \\
\hline Triglycerides (mg/dl) & $136.2^{\mathrm{a}}$ & $128.33^{\mathrm{ab}}$ & $117.23^{\mathrm{b}}$ & $117.03^{\mathrm{ab}}$ & 35.32 & $* *$ \\
\hline Malondialdehyde (nmol/mg) & $5.2^{\mathrm{a}}$ & $4.49^{\mathrm{b}}$ & $4.75^{\mathrm{ab}}$ & $4.37^{\mathrm{b}}$ & 0.07 & $*$ \\
\hline pHu of meat & 6.02 & 5.96 & 5.98 & 5.84 & 0.02 & NS \\
\hline Drip loss \% & $26.78^{\mathrm{a}}$ & $17.22^{\mathrm{b}}$ & $19.11^{\mathrm{b}}$ & $17.33^{\mathrm{b}}$ & 1.49 & $*$ \\
\hline
\end{tabular}

$a, \mathrm{~b}$ and $\mathrm{c}$ : Means in the same row having different superscripts differ significantly.

differences $(\mathrm{P}>0.05)$ in crude protein among groups supplemented with lemon grass in meat traits in broilers. Total cholesterol percentages were higher in the groups fed diet contains $100 \mathrm{mg} / \mathrm{kg}$ LGO, and lower in the groups fed diets contain $150 \mathrm{mg} / \mathrm{kg}$ Vit $\mathrm{E}$ and $150 \mathrm{mg} / \mathrm{kg}$ LGO than the control. Also, Total cholesterol percentages were lower in groups fed diet contains $150 \mathrm{mg} / \mathrm{kg} \mathrm{LGO}$ when compared with diets contains $150 \mathrm{mg} / \mathrm{kg}$ Vit E. Triglycerides percentages were significantly lower $(\mathrm{P}<0.01)$ in treatment diets compared with the control. There were no differences between groups fed diets contains $150 \mathrm{mg} / \mathrm{kg}$ LGO 
and150mg/kg Vit E. There were no differences in $\mathrm{pHu}$ among experimental groups. Also, Drip loss $\%$ of meat were $(\mathrm{P}<0.05)$ significantly decreased in all experimental groups.

In connection with total cholesterol contents in meat, it decreased with adding $200 \mathrm{mg}$ vitamin $\mathrm{E}$ in pigs feed (Souza and Silva, 2006) and in poultry feed (Zdanowska-Sąsiadek, et al., (2016). The concentrations of malondialdehyde (MDA) in muscles were significantly $(\mathrm{P}<0.05)$ lower in experimental groups compared with the control group. There were no differences between rabbits fed diets contained $150 \mathrm{mg} \mathrm{LGO} / \mathrm{kg}$ and $150 \mathrm{mg}$ VitE $/ \mathrm{kg}$ in meat MDA concentration. These results were in agreement with Al-Sagheer, et al., (2017a) which found that supplemented growing NZW rabbits with lemon grass oil significantly $(\mathrm{P}<0.05)$ decreased MDA concentrations compared to the control in heat stress condition. Also, Zhang et al., (2012) mention that supplemented diet with vitamin E suppressed MDA in rabbit meat.

\section{Economic Efficiency:}

The economic efficiency of the experimental diets is summarized in Table 6. Rabbits fed on diets supplemented with $150 \mathrm{mg} \mathrm{LGO} / \mathrm{kg}$ recorded the best value of relative economic efficiency $110.30 \%$ followed by $150 \mathrm{mg} \mathrm{Vit} \mathrm{E} / \mathrm{kg}$ diet. $106.29 \%$ when compared to the control group.

Table 6: Input- output analysis and economic efficiency of experimental dietary treatment.

\begin{tabular}{|l|c|c|c|c|}
\hline \multirow{2}{*}{ Item } & \multicolumn{4}{c|}{ Experimental groups } \\
\cline { 2 - 5 } & Control & $\begin{array}{c}\text { VitE } \\
150 \mathrm{mg} / \mathrm{kg}\end{array}$ & $\begin{array}{c}\text { LGO } \\
100 \mathrm{mg} / \mathrm{kg}\end{array}$ & $\begin{array}{c}\text { LGO } \\
150 \mathrm{mg} / \mathrm{kg}\end{array}$ \\
\hline Body weight gain (g) & 1543.75 & 1712.5 & 1557.5 & 1748.13 \\
\hline Price/kg sold for body weight & 54.00 & 54.00 & 54.00 & 54.00 \\
\hline Total revenue / rabbit (LE) & 83.36 & 92.47 & 84.10 & 94.23 \\
\hline Total feed consumption/rabbit (kg) & 5.46 & 5.54 & 5.29 & 5.32 \\
\hline Price/kg feed (LE) & 5.20 & 5.45 & 5.50 & 5.65 \\
\hline Total feed cost/rabbit (LE) & 28.39 & 30.19 & 29.09 & 30.05 \\
\hline Net revenue $^{1}$ (LE) & 54.97 & 62.28 & 55.01 & 64.18 \\
\hline Economic efficiency $^{2}$ & 193.62 & 206.29 & 189.10 & 213.57 \\
\hline Relative economic efficiency $^{3}(\%)$ & 100.00 & 106.29 & 97.66 & 110.30 \\
\hline
\end{tabular}

Total price for feeds was calculated according to the price of different ingredients available in ARE. Price of one Kg live weight was $54 \mathrm{LE},{ }^{1}$ Net revenue $=$ total revenue/ chick- total feed cost/chicks, ${ }^{2}$ Economic efficiency $=$ net revenue/ total feed coast/chicks, 3Relative economic efficiency of the control, assuming that the relative E1 of the control $=100$ 
Conclusively, it could be concluded that supplementing dietary with 150 $\mathrm{mg} / \mathrm{kg}$ lemongrass oil or vitamin $\mathrm{E}$ improved growth performance, nutrient digestibility and meat quality of growing rabbits without probable side effects. Lemongrass oil improved carcass characteristics while vitamin $E$ had no effect. Supplementation of $150 \mathrm{mg}$ LGO $/ \mathrm{kg}$ led to improvement economic efficiency than that of $150 \mathrm{mg} \mathrm{VitE} / \mathrm{kg}$ diet and free from additives.

\section{REFERNCES}

Abe, S.; Maruyama, N.; Hayama, K.; Inuoye, S.; Oshima, H. and H. Yamauchi (2004). Suppression of neutrophils recruitment in mice by geranium essential oil. Mediators Inflamm,13(1):21-24.

Aftab, K.; Ali, M. D.; Aijaz, P.; Beena, N.; Gulzar, H. J. and K. Sheikh (2011). Determination of different trace and essential element in lemon grass samples by X-Ray flouresence spectroscopy technique. Int. Food Res. J., $18: 265-270$.

Akhila, A. (2010). Essential oil bearing plants: The genus cymbopogon. Edited by: AnandAkhila. BrocaRaton, FL: CRC Press Taylor \& Francis Group.

Al-Sagheer, A. A.; Daader, A. H.; Gabr, H. A. and Elham A. Abd El-Moniem (2017a). Palliative effects of extra virgin olive oil, gallic acid and lemongrass oil dietary supplementation on growth performance, digestibility, carcass traits, and antioxidant status of heat-stressed growing New Zealand White rabbits. Environ. Sci. Polluted Res., 24:6807-6818.

Al-Sagheer, A. A.; Mahmoud, H. K.; Reda, F. M.; Mahgoub, S. A. and M. S. Ayyat (2017b). Supplementation of diets for Oreochromis niloticus with essential oil extracts from lemongrass (Cymbopo goncitratus) and geranium (Pelargonium graveolens) and effects on growth, intestinal microbiota, antioxidant and immune activities. Aquaculture Nutrition. 24:1006-1014.

AOAC, Association of Official Analytical Chemists (1996). Association of Official Analytical Chemists $16^{\text {th }}$ Edn., Gaithersburd, MD, USA.

Azzi, A.; Ricciarelli, R. andJ. M.Zingg (2002).Non-antioxidant molecular functions of alpha-tocopherol (vitamin E). FEBSLett, 22: 8-10.

Bachiega, T. F. and J. M. Sforcin (2011). Lemongrass and citral effect on cytokines production by murine macrophages. J. of Ethnopharmacol Ogy, 137(1), 909-913. 
Barlow, S.M. (1990). Toxicological aspects of antioxidants used as food additives. In "Food Antioxidants". Hudson B. J. F. (Ed.) Elsevier Applied Science. London and New York.

Bazan, N.G.; Molina, M.F.andW.C.Gordon (2011). Docosahex-aenoic acid signal olipidomics in nutrition: significance in aging, neuroin Flammarion, macular degeneration, Alzheimer's, and other neurodegenerative diseases. Annual Review of Nutrition. 31:321-351.

Bharti, S. K.; Kumar, A.; Prakash, O.; Sharma, N. K. and S.Krishnan (2013).Essential oil of cymbopo goncitratus against diabetes: Validation by in vivo experiments and computational studies. Scientific Reports; 2(3):1-9. doi:10.4172/scientificreports. 688

Blasco, A.; Ouhayoun, J. andG.Masoero (1993). Harmonization of criteria and terminology in rabbit meat research. World Rabbit Sci, 1:3-10.

Botsoglou, N.A.; Florou-Paneri, P.; Christaki, E.; Giannenas, I.and A. B. Spais (2004). Performance of rabbits and oxidative stability of muscle tissues as affected by dietary supplementation with oregano essential oil. Archives of Animal Nutrition, 58,(3):209-218.

Brand-Williams, W.; Cuvelier, M.E. and C.Berset (1995). Use of a free radical method to evaluate antioxidant activity. Food Sci. Technol., 28, 25

Brigelius-Flohe, R.; Azzi, A.; Ricciarelli, R. and J. M.Zingg (2002).Nonantioxidant molecular functions of alpha-tocopherol (vitamin E). FEBS Lett, $519,8-10$.

Brigelius-Flohe', R. and M. G. Traber (1999). Vitamin E: function and metabolism. Faseb Journal, 13: 1145-1155.

Carlini, E. A.; De-Contar, J. P.; Siloai-Filho, A. R.; De-Silreiral-Filho, N. G.; Fronchtengarten, M. L. and O. F.Bveno (1986). Pharmacology of lemon grass (cymbopogoncitratusStapf). J. Ethnoparmacol; 17(1):37-64.

Cardinali, R.; Cullere, M. and A. Dal Bosco (2015). Oregano, rosemary and vitamin $\mathrm{E}$ dietary supplementation in growing rabbits: effect on growth performance, carcass traits, bone development and meat chemical composition. Livestock Science 175:83-89.

Cheeke, P.R. (1987). Rabbit Feeding and Nutrition. Academic Press, INC.

Combes, S. (2004). Valeurnutritionnelle de la viande de lapin, 'INRA Productions Animales, 17(5):373-383.

Duncan, D.B. (1955). Multiple range and multiple F tests. Biometrics, 11: 1-42. 
Faruq, M.O. (1994). TLC technique in the component characterization and quality determination of Bangladeshi lemongrass oil. (Cymbop ogon citratus DC stapf.) Bangladesh. J. Sci. Ind. Res. 29:27-38.

Gazola, R.; Machado, D.; Ruggiero, C.; Singi, G.and M.Mecado (2004). Lippiaalba, Melissa officinalis and cymbopogon citrates effects of the aqueous extracts on the isolated hearts of rats. Pharmacol Res;50 (5):477480.

Gil, M.D.; Bañòn, S.J.; Cayuela, J.M.; Laencina, J. and M.D. Garrido (2001). Utilizaciòn de extractos de plants como antioxidants naturalesen carne $\mathrm{y}$ productoscàrnicos: revisiòn. Eurocarne, 101: 1-10.

Hern 'andez P. and F. Gondret(2006). Rabbit meat quality in recent advances in rabbit Sciences, L. Maertens and P. Coudert, Eds.,pp.269-290, Melle, Belgium.

Hettiarachchy, N.S.; Glenn, K.C.; Gnanaesbandam, R. and M.G. Johnson (1996). Natural antioxidant extracts from fenugreek (Trigonella fenunm graecum) for ground beef patties. J. Food Sci., 61:516-521.

Holetz, F. B,; Ueda-Nakamura, T.;Filho, B. D.; Cortez, D. G.;Morgado-Diaz, J. A. and C. V.Nakamura (2003). Effect of essential oil of ocimumgratis simum on the typano somati dherpeto monassamuel pessoai. Acta Protozool; 42: 269-276.

Kassahun, A. and F. Gezu (2019). Chemical composition and physico-chemical analysis of eucalyptus globulus leave and oil. Sci. J. of Chem., 7(2): 36-38. http://www.science publishing group.com/j/sjc

Krieg,R.; Vahjen, W.;Awad, W.;Sysel, M.; Kroeger, S.;Zocher, e.;Hulan,H.W.;Arndt G. andJ. Zentek (2009). Performance, digestive disorders and the intestinal microbiota in weaning rabbits are affected by a herbal feed additive. World Rabbit Sci., 17: 87 - 95.

Lundström, K. andG.Malmfors(1985). Variation in the light scattering and water holding capacity along the porcine longissimus dorsi muscle. Meat Sci., 15:203-214.

Malee, B.; Petchply, D.; Chyratch, S. and C. Sawangwong (2000). Local Herb. Herb Research Institute, Department of Medical Science, Bangkok.Lemon grass oil.

Mansour, H. A.; Newairy, A. S.; Youset, M. I. and M. I. Sheweita (2002). Biochemical study on the effects of some Egyptian herbs in alloxan-induced diabetic rats. Toxicology; 170(3):221-228. 
Masuda, T.; Odaka, Y.; Ogawa, N.; Nakamoto, K. and H.Kuninaga (2008). Identification of geranic acid, a tyrosinase inhibitor in lemongrass (Cymbopogon citratus). J. Agric. Food Chem., 56(2):597-601.

Morissey, P.; Buckley, D.; Sheehy, P. and F. Monahan (1994). Vitamin E and meat quality. Proceding of Nutrition Soc., 53: 289-295.

Mukhtar A.M.; Mohamed, K.A.; Amal, O.A. and A.H.Ahlam(2012). Effect of different levels of lemon grass oil (LGO) as a natural growth promoter on the performance, carcass yields and serum chemistry of broiler chicks. Egypt. Poultry. Sci., 33: 1-7.

Nakagawa, T.; Mazzali, M.; Kang, D. H.; Kanellis, J.; Watanebe, S. and L. G. Sanchez-Lozada (2003). Hyperuricemia causes glomerular hypertrophy in the rat. Am. J. Nephrol; 23:2-7.

Negrelle, R. R. and E. C. Gomes (2007). Cymbopogon citrates (DC) Stapf: chemical composition and biological activities. Revista Brasileira De Plantas Medicinais, Botucatu; 9(1):80-92.

NRC, (1977). National Research Council. Nutrient Requirements of Rabbits. Nat. Acad. Sci., $1^{\text {st }}$ edition, Washington, Dc, USA.

Omer, H. A. A. ; Elallawy, H. M. H.; El-Samee, L. D. A. and N.Maghraby (2010). Productive performance of rabbits fed diets containing lemongrass or active dried yeast. American-Eurasian J. of Agric. and Environmental Sci.7(2):179-187.

Omojola, A. B. and A. O. K.Adesehinwa (2006). Meat Characteristics of Scalded, Singed and Conventionally dressed rabbit carcasses. World J. Zool., 1(1): 24-29.

Oussalah, M.; Caillet, S.; Saucier, L. and M. Lacroix (2007). Inhibitory effects of selected plant essential oils on the growth of four pathogenic bacteria: E. coli O157: H7, Salmonella typhimurium, Staphylococcus aureus and Listeria monocytogenes. Food Control, 18(5), 414-420.

Puatonachokchai, R.; Kishida, H.; Denda, A.; Murata, N.; Konishi, Y. and U.Vinitketkumnuen(2002). Inhibitory effects of lemon grass (Cymbopogon citrates stapf) extract on the early phase of hepatocarcinogenesis after initiation with ethyinitrosamine in male fischer 344 rats. Cancer Letters. 183:9-15.

Roth, E. (2000). Oxygen free radicals and their clinical implications. Acta Chirurgicahungarica, 36, 302-305.

SAS (2001). Statistical Analysis System, User's Guide Version 8.2, Cary NC. USA. 
Selim N. A.; Abdel-Khalek A. M.; Nada S.A. and Sh.A. El-Medany (2007). Response of growing rabbits to dietary antioxidant vitamins EAND C. 1. Effect on performance. $9^{\text {th }}$ World Rabbit Congress - Verona - Italy.

Souza, V.L.F. and R.S.S.F. Silva (2006). Dietary vitamin E supplementation on cholesterol and cholesterol oxides of pig meat and cooked ham. Braz. Arch. Biol. Technol., 49: 197-205.

Tarkang, P. A.; Agbor, G. A.; Tsabang, N.; Tchokouaha, R. Y.; Tchamgoue, D. A. andD. Kemeta (2012). Effectof long-term oral administration of the aqueous and ethanol leaf extract of cymbopogoncitrates (DC. Ex Ness) Stapf. Ann. Biol. Res., 3(12):5561-5570.

Tiwari, M. R.; Shah, B. and A. K. Jha (2019). Evaluation of lemon grass (Cymbopogon citrates) oil as a growth promoter on broiler chicken. J. of agric. and Environ., 20:226-236.

Tognolini, M.; Barocelli, E.; Ballabeni, V.; Bruni, R.; Biandi, M. and M.Impicciatore (2006).Comperative screening of plants essential oils, phenylpropanoid as basic core for antiplatelet activity. Life Sci. 78(13):1419-1432.

Wall, R.; Ross, R.P.; Fitzgerald, G.F.andC. Stanton (2010). Fattyacids from fish: the anti-inflammatory potential of long-chainomega-3 fatty acids,"Nutrition Reviews. 68(5):280-289.

Wannissorn, B.; Jarikasem, S.; Siriwangchai, T. and S. Thubthimthed (2005). Anti-bacterial properties of essential oils from Thai medicinal plants. Fitoterapia; 76:233-236.

Zdanowska-Sąsiadek, Ż.; Michalczuk, M.; Poławska, E.; Damaziak, K.; Niemiec, J. andA. Radzik-Rant (2016). Dietary vitamin E supplementation on cholesterol, vitamin E content, and fatty acid profile in chicken muscles. Can. J. Anim. Sci., 96: 114-120.

Zhang, W.; Wang, X. P.; Wang, C. Y and F. C. Li (2012). Effect of dietary vitamin $\mathrm{E}$ supplementation on meat quality, vitamin $\mathrm{E}$ contents and oxidative stability of rabbit meat. World Rabbit Science Association. Proceedings $10^{\text {th }}$ World Rabbit Conference, September 3 - 6, 2012-Sharm El-Sheikh,Egypt, 871-874. 


\title{
تأثير علائق زيت حشيشة الليمون أو فيتامين هـ علي الأداء ومعاملات الهضم ومواصفات الذبيحه وجودة اللحم في الار انب هيتب الأبو
}

\author{
حمدي محمد أحمد الكومي - عنايات أ بوالعزايم - جورج عزت يونان إنان

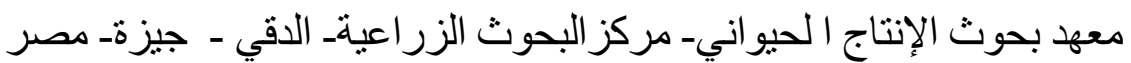

تم إجر اء هذه التجربة لمعرفة تأثيرزيت حشيشة الليمون او فيتامين هـ على الأداء

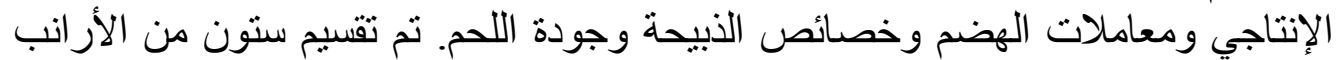

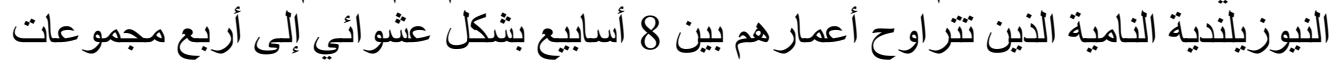

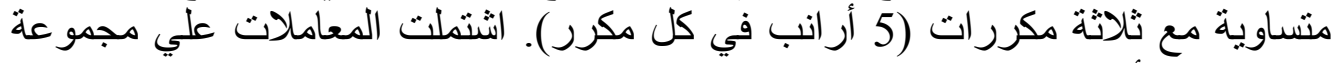

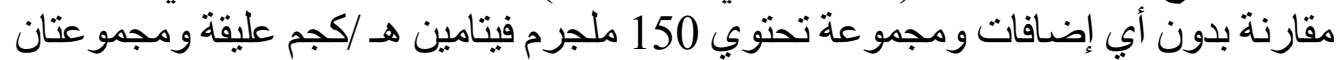

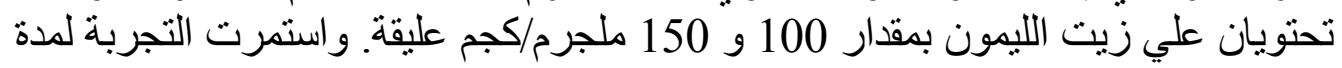
42يوم مع تو افر الغذاء و الماء بشكل دائم.

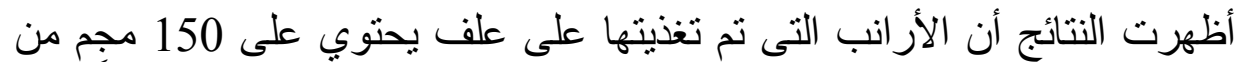

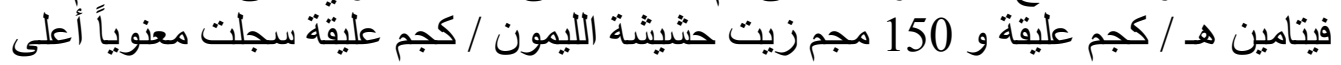

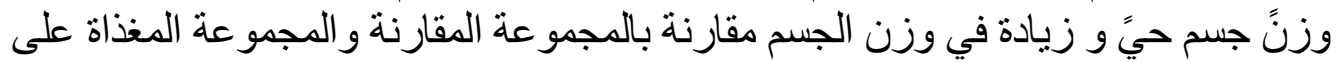
100 مجم زيت حشيشة الليمون / كجم عليقة. سجلت المجمو عادة المغذاة علي علي عليقة اليقة تحتوبي

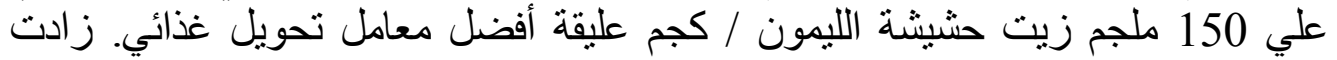

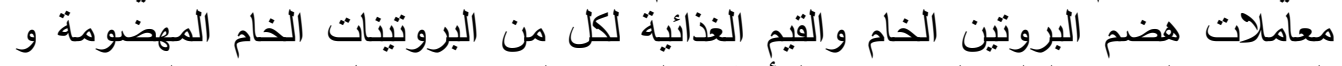

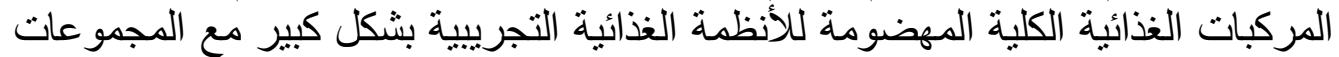

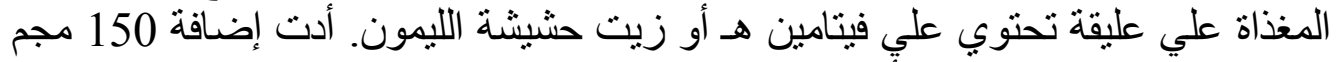

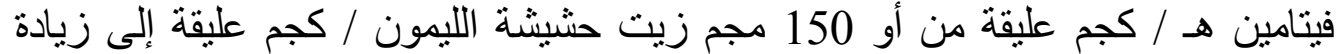

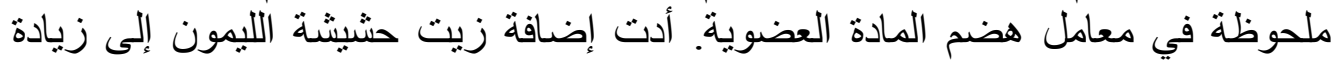

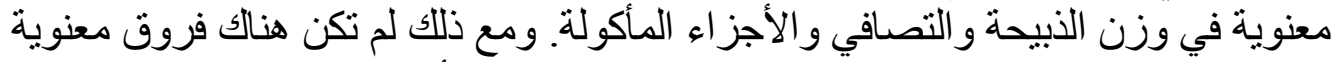

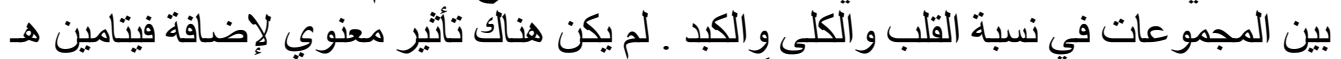

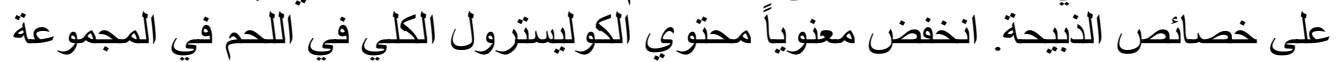

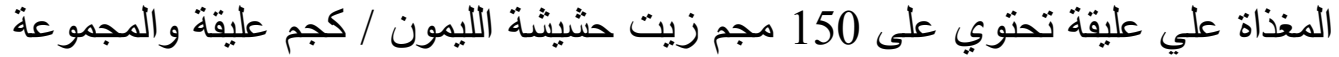

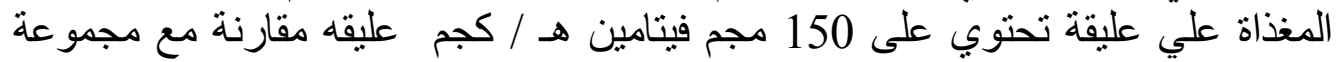

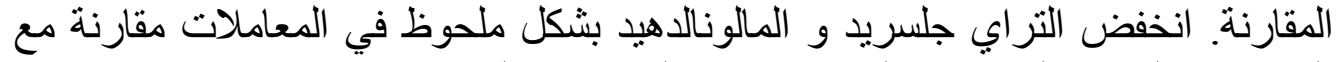
المجموعة المقارنة.لم تكن هنالك فروق بين المجموعة التي تم تغذيتها بـ 150 مجم زيت 


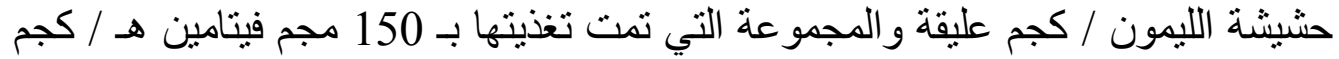

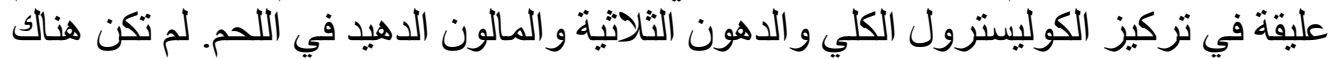

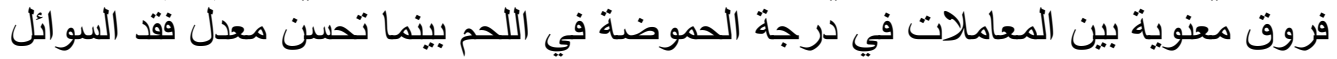

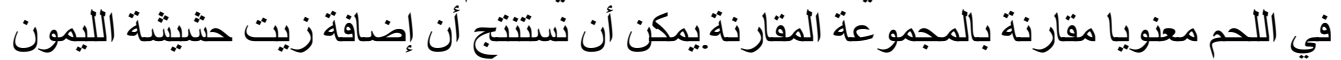

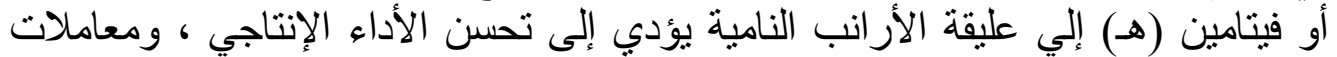

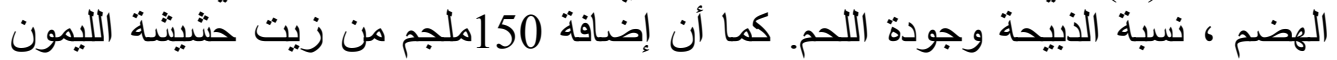

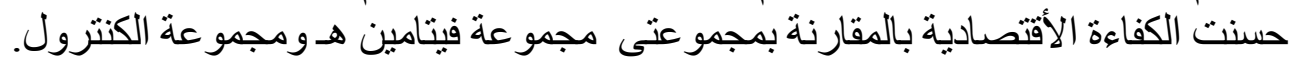

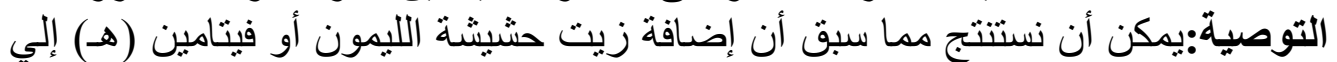

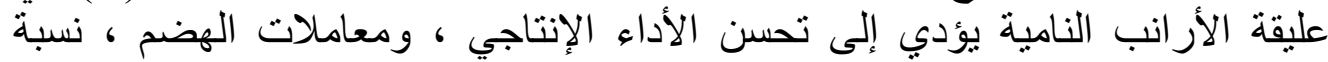

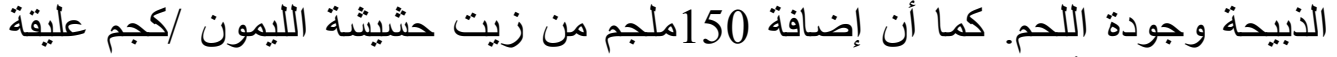
حسنت الكفاءة الأقتصادية بالمقارنة بمجمو عنى مجمو عة فيتامين هـ ومجمو عة الكنترول. 